\title{
Large cohort study on the relation between cigarette smoking and senile dementia without cerebrovascular lesions
}

Takeshi Hirayama

\begin{abstract}
Objective-To examine the association between senile dementia and cigarette smoking.

Design-Prospective cohort study with 17 years of follow up (1966-82).

Subjects -265118 adults $\geqslant 40$ years of age (95\% sample of the census population) residing in 29 health centre districts in six prefectures in Japan.

Main outcome measures - Cause specific mortality rates associated with various lifestyles including diet, smoking, and alcohol use. For this analysis the main outcome measures were senile dementia with or without cerebrovascular lesions as the direct cause of death, the underlying cause of death, or a coexisting disease.

Results - The risk of death reported as senile dementia without cerebrovascular lesions $(n=120)$, mostly composed of Alzheimer's disease, was significantly higher in cigarette smokers relative to never smokers (relative risk 1.61, $90 \%$ confidence interval $1 \cdot 10$ to $2 \cdot 38$; two sided $p=0.042)$. A significant dose-response relation was observed for men of 75 and older, with relative risks for never smokers and for daily smokers of 1-14, $15-19$, and $\geqslant 20$ cigarettes per day equal to $1.00,1 \cdot 73,3 \cdot 15$, and $3 \cdot 10$, respectively (two sided $p=0.036$ for trend). A similar trend was seen for men of 70 and older. Conclusions - Although misclassification of cerebrovascular causes of death as senile dementia cannot be excluded completely, the positive association between cigarette smoking and senile dementia without cerebrovascular lesions provides further rationale for smoking prevention and cessation.
\end{abstract}

(Tobacco Control 1992; 1: 178-9)

Introduction

In a recent article about the relation between

Institute of Preventive Oncology, HI

Building, 1-2

Sadohara-cho,

Ichigaya, Shinjuku-ku,

Tokyo, Japan 162

$\mathrm{T}$ Hirayama confirm by prospective studies the inverse association observed by case-control investigations. ${ }^{1}$ One such prospective study was reported recently by Hebert et al, which showed no significant association between cigarette smoking and Alzheimer's disease. ${ }^{2}$

We also studied the issue in a large scale cohort study conducted in Japan and observed a significant positive association between cigarette smoking and senile dementia without cerebrovascular lesions. The possible reasons for conflicting results of published studies are briefly discussed below.

\section{Subjects and methods}

From October to December 1965 the lifestyles of 265118 adults aged 40 and over who lived in 29 health centre districts in six prefectures (Miyagi, Aichi, Osaka, Hyogo, Okayama, Kagoshima) in Japan were surveyed by questionnaire. The questionnaire included such items as smoking, drinking, and occupation (figure 1) and was completed during a home visit, by public health nurses. ${ }^{3}$ These subjects, $95 \%$ of the census population (1 October 1965 ) of the target age group, were carefully followed up for 17 years (1966-82) by establishing a record linkage system between the risk factor records studied in 1965 , a current residence list obtained by a specially planned annual census, and death certificates. A total of 55523 deaths occurred in this cohort during the 17 year period ( 31979 in men and 23544 in women). Further details on the study methods have been published previously. ${ }^{3}$

Among 3849637 observed person-years for people of 40 and over during the 17 year period in the six prefectures (1709273 for men, 2140364 for women), 69 death certificates recorded senile dementia with cerebrovascular lesions (32 for men, 37 for women) and 120 recorded senile dementia without cerebrovascular lesions (49 for men, 71 for women). I carefully checked and scrutinised each of these 189 death certificates. Of the 120 death certificates recording senile dementia without cerebrovascular lesions, 11 recorded the dementia as the direct cause of death, 47 as the underlying cause, and 62 as a coexisting morbid condition.

\section{Results}

The numbers of deaths from senile dementia without cerebrovascular lesions and observed person-years by sex, age group, and smoking status are shown in the table. Six of the 120 


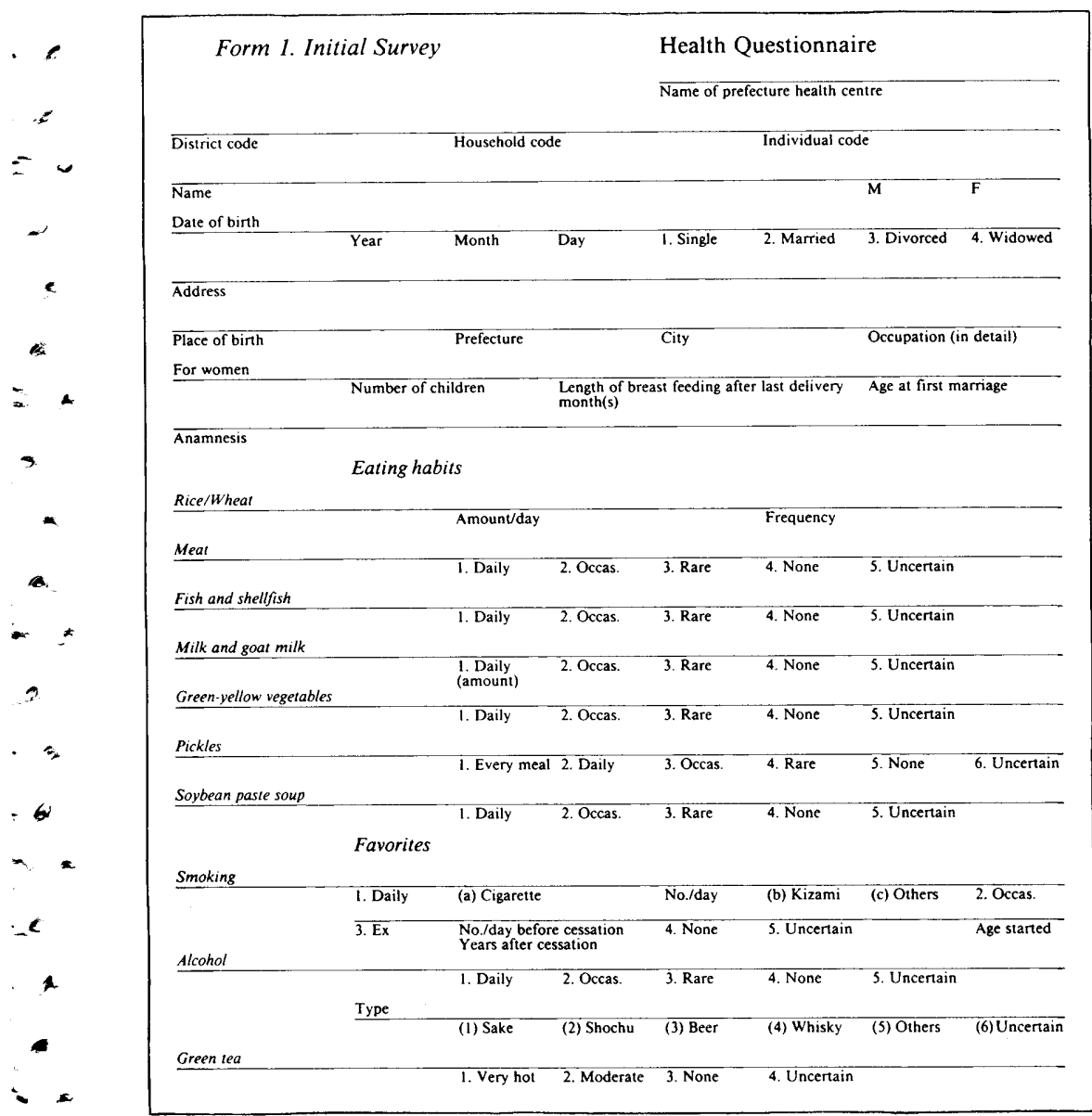

Figure 1 Questionnaire used in original survey, 1965
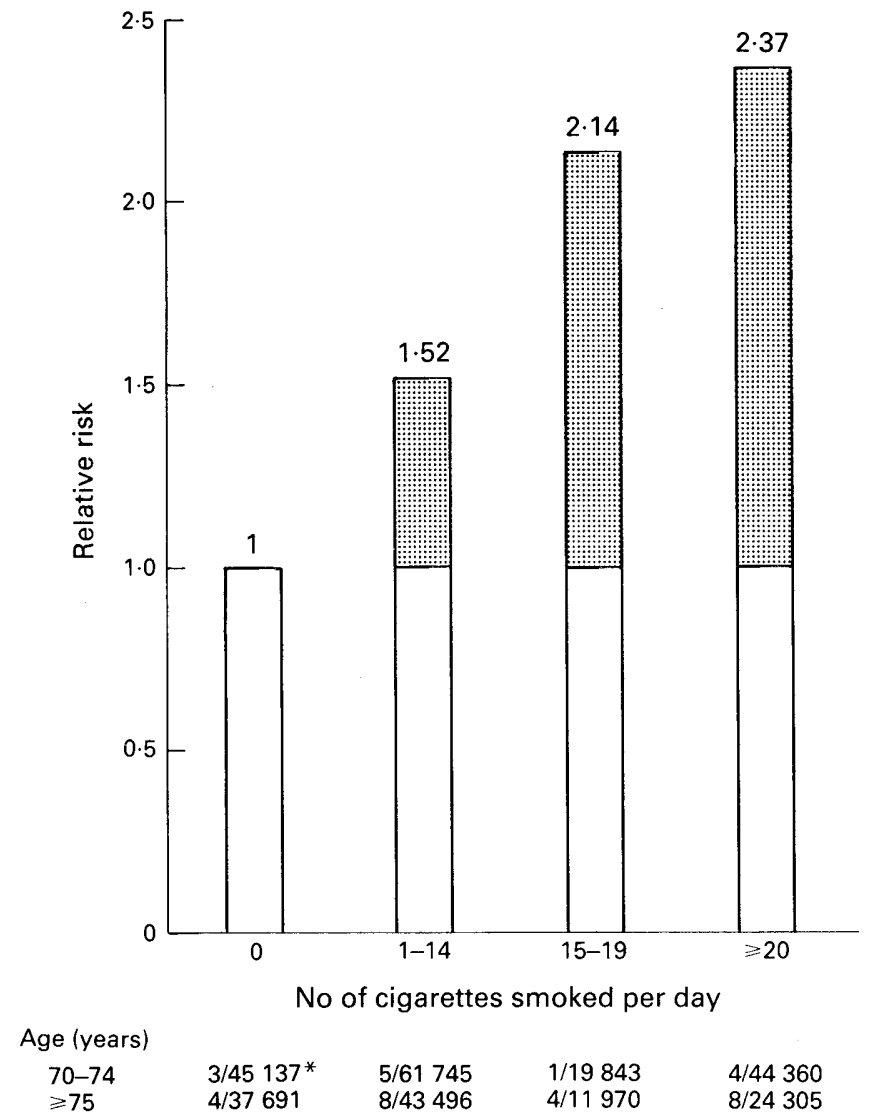

$\begin{array}{crcr}3 / 45137^{*} & 5 / 61745 & 1 / 19843 & 4 / 44360 \\ 4 / 37691 & 8 / 43496 & 4 / 11970 & 8 / 24305 \\ \text { Mantel-extension } \chi=1.849, \text { two sided } p=0.064\end{array}$

Mantel-extension $\chi=1.849$, two sided $\mathrm{p}=0.0$
${ }^{*}$ Deaths divided by observed person-years.

Figure 2 Relative risk of developing Alzheimer's disease by number of cigarettes smoked per day in men aged 70 and over (cohort study, 1966-82, fapan)
Numbers of deaths among people having senile dementia without cerebrovascular lesions

\begin{tabular}{cccccc}
\hline & \multicolumn{2}{c}{ Daily smokers } & & \multicolumn{2}{c}{ Never smokers } \\
\cline { 6 - 6 } \cline { 5 - 6 } $\begin{array}{c}\text { Age group } \\
\text { (years) }\end{array}$ & $\begin{array}{c}\text { No of } \\
\text { deaths }\end{array}$ & $\begin{array}{c}\text { Person-years } \\
\text { observed }\end{array}$ & & $\begin{array}{c}\text { No of } \\
\text { deaths }\end{array}$ & $\begin{array}{c}\text { Person-years } \\
\text { observed }\end{array}$ \\
\hline & \multicolumn{5}{c}{ Men } \\
& & & \\
$55-59$ & 1 & 253187 & & 51081 \\
$60-64$ & 2 & 236209 & & 0 & 55032 \\
$65-69$ & 0 & 204146 & & 1 & 56328 \\
$70-74$ & 10 & 138163 & & 3 & 45137 \\
$\geqslant 75$ & 26 & 91101 & & 4 & 37691 \\
& & & Women & & \\
$55-59$ & 0 & 39321 & & 1 & 355775 \\
$60-64$ & 3 & 41950 & & 3 & 324083 \\
$65-69$ & 2 & 39605 & & 4 & 276018 \\
$70-74$ & 3 & 29117 & & 17 & 194804 \\
$\geqslant 75$ & 5 & 23179 & & 28 & 150234 \\
\hline
\end{tabular}

Mantel-Haenszel $\chi 2.038$, two sided $\mathrm{p}=0.042$; relative risk $1 \cdot 61(90 \%$ confidence interval $1 \cdot 10$ to $2 \cdot 38)$.

deaths are excluded: one of a male ex-smoker, four of women whose smoking status was unknown, and one of a female daily smoker who was diagnosed as heavy senile dementia at the exceptionally young age of 42 .

The relative risk for senile dementia without cerebrovascular lesions was $1.61(90 \%$ confidence interval 1.10 to 2.38 ; two sided $p=0.042$ ) among daily smokers relative to never smokers. Trends in men and women were similar. The relative risks were $1.58(0.87$ to 2.86$)$ in male smokers and $1.65(1.00$ to 2.72$)$ in female smokers. Adjustment for socioeconomic conditions did not influence the results.

Relative risks for other factors of lifestyle (daily $v$ non-daily consumption) were 1.09 $(0.75$ to 1.59$)$ for milk drinking, $1.04(0.75$ to $1.45)$ for consumption of soybean paste soup, $0.93(0.65$ to 1.34$)$ for alcohol drinking, 0.87 $(0.62$ to 1.21$)$ for consumption of green-yellow vegetables, $0.66(0.47$ to 0.93$)$ for fish eating, and $0.46(0.18$ to 1.17$)$ for meat eating. Relative risks for senile dementia with cerebrovascular lesions $(\mathbf{n}=69)$ were, on the other hand, $1 \cdot 17$ (0.64 to $2 \cdot 13)$ for alcohol drinking, $1.05(0.65$ to $1.71)$ for daily cigarette smoking, $0.99(0.65$ to $1.50)$ for fish eating $0.72(0.47$ to 1.09$)$ for consumption of green-yellow vegetables, 0.65 $(0.37$ to 1.14$)$ for milk drinking, $0.51(0.16$ to $1.63)$ for meat eating, and $0.48(0.33$ to 0.71$)$ for consumption of soybean paste soup. Thus daily cigarette smoking was identified as the strongest risk enhancing factor for senile dementia without cerebrovascular disease, the effect being far stronger than for senile dementia with cerebrovascular disease. In the case of senile dementia without cerebrovascular disease the disease developed five years earlier in daily smokers, with the ratio of observed to expected cases being almost 1.0 when the expected frequency in daily smokers was calculated using the age specific rate for never smokers who were five years older. ${ }^{4}$

In men aged 75 and over a significant doseresponse relation was observed, with the relative risks for never smokers and smokers of 1-14, 15-19, and 20 or more cigarettes per day being $1.00,1.73,3.15$, and $3.10\left(\chi^{2}\right.$ for trend 2.099 , two sided $p=0.036$ ). Such a trend was also seen in men aged 70 and over (figure 2). 


\section{Discussion}

QUALITY OF THE STUDY MATERIALS

This study is based on the information recorded in death certificates regarding senile dementia. The quality of death certificates in Japan may be among the best in the world, as much effort has been made in the past on the initiative of the Ministry of Health and Welfare to improve the quality of death certificates, especially for elderly people, along the lines of international guidance provided by the World Health Organisation.

Improvement due to this effort is exemplified by the decline in the number of death certificates carrying the diagnosis of "senility" in recent years in Japan. Mortality from senility per 100000 population as recorded on death certificates decreased from 100.3 in 1947 to 70.2 in $1950,58 \cdot 0$ in $1960,38.1$ in $1970,27.6$ in 1980, and 19.6 in 1990. This reduction is a clearcut reflection of the continuous efforts of the Ministry of Health in asking physicians to resubmit death certificates when judged to be incomplete and asking them to describe existing pathological conditions with as much detail as possible. Our large scale cohort study was conducted after considerable improvement had been made. Therefore, in most death certificates in this study the direct cause of death, underlying causes of death, and coexisting illnesses were minutely recorded, including the diagnosis of senile dementia.

I do not deny the possibility of underrecording, especially when dementia was clinically not severe. However, for those recorded as having senile dementia, I consider the majority to have had a fairly valid diagnosis. As there is no reason to consider the degree of under-recording to be different for smokers and non-smokers, or by other lifestyles, and as no other more valid resources for epidemiological study were readily available, I decided to use death certificates as study materials while recognising the limitation of this approach. Without further validation of the diagnosis of dementia, the possibility of misclassification cannot completely be excluded as contributing to the association between cigarette smoking and dementia without cerebrovascular lesions.

COMPARISON OF CURRENT RESULTS WITH THOSE OF PREVIOUSLY PUBLISHED STUDIES

My results are similar to those of two published studies, ${ }^{5,6}$ but they are different from those in a Dutch study ${ }^{1}$ and in two other studies. ${ }^{2,7}$

Hebert et al reported a prospective study on cigarette smoking and Alzheimer's disease and found no significant association. ${ }^{2}$ In interpreting the results of their study, one has to take into consideration an usually high incidence of Alzheimer's disease: out of 513 subjects (mean age 73), 76 and 146 suffered from probable and possible Alzheimer's disease, respectively, and only 291 (57\%) remained unaffected during less than five years of follow up. Also, cases of probable
Alzheimer's disease were compared with controls, the controls including both possible cases of Alzheimer's disease and unaffected cases.

Almost all other published studies were based on the case-control method and the information on smoking was obtained mostly from the next-of-kin both for the study group and the control group. The issue is by nature not suited to be studied by the case-control method, as valid information cannot be obtained from patients with dementia. Information obtained from family members may also be uniformly biased as no one would allow a family member suffering from dementia to regularly handle fire, as in smoking a cigarette. Such bias can cause systematic misclassification of the smoking status of the patient and not of the controls. In addition, though the behaviour of demented patients is in general strictly under the observation of family members, the behaviour of control subjects is mostly unobserved by family members, particularly in daytime. Therefore the most valid answers to the issue can be obtained only from a large scale cohort study, like the one described here. Subjects were interviewed before they developed dementia and the risk of subsequently developing the disease was measured according to smoking behaviour when patients' mental conditions were still normal. The duration of each disease is in principle recorded on the death certificate. When the approximate time of onset of dementia was estimated by the duration of the disease, the mental conditions of all cases but two were judged to be normal at the start of this cohort study.

\section{UNDERLYING MECHANISMS}

One conceivable mechanism by which cigarette smoking might increase the risk of Alzheimer's disease, as suggested in this study, could be an acceleration of the natural consequences of general aging. However, other more direct explanations might also be possible, of which details will be discussed in later communications.

1 van Duijn C, Hofman A. Relation between nicotine intake and Alzheimer's disease. BMF 1991; 302: 1491-4

2 Hebert LE, Scherr PA, Beckett LA, Fundenstein HH, Albert MS, Chown MJ, Evans D. Relation of smoking and alcohol consumption to incident Alzheimer's disease. Am $\mathcal{F}$ Epidemiol 1992; 135: 347-55.

3 Hirayama T. Life-style and mortality. In: Wahrendorf J, ed. Contributions to epidemiology and biostatistics 6. Basle: Karger, 1990.

4 Hirayama $T$. Health effects of active and passive smoking. In: Aoki M, Hisamichi S, Tominaga S, eds. Smoking and health 1987. Proceedings of the sixth world conference and smoking and health s of the sixth world conference on smoking and health, Tokyo, 9-12 November

5 Shalat SL, Seltzer B, Pidcock C, Baker EL. Risk factors for Alzheimer's disease; a case-control study. Neurology Alzheimer's disease;

6 Joya CJ, Pardo CA, Londono JL. Risk factors in clinically diagnosed Alzheimer's disease; a case-control study in Colombia (South America). Neurobiol Aging 1990; 11: 296.

7 Graves $A B$, van Duijn $C M$, Chandra V, Fratiglioni L, Heyman A, Jorm AF, et al for the Eurodem Risk Factors Research Group. Alcohol and tobacco consumption as risk factors for Alzheimer's disease: a collaborative reanalysis of case-control studies. Int J Epidemiol 1991; 20 : 


\section{Translations of abstract}

\section{Grande étude de groupe sur la relation entre la consommation de cigarettes et la demence senile sans lesions cérébrovasculaires}

Takeshi Hirayama

\section{Résumé}

Objectif: Examiner l'association entre la démence sénile et la consommation de cigarettes.

Méthode: Etude prospective de groupe avec un suivi sur 17 ans (1966-82).

Sujets: 265118 adultes âgés de plus de 40 ans (un échantillon de $95 \%$ de la population recensée) résidant dans le rayon d'intervention de 29 centres de soin situés dans six préfectures du Japon.

Base d'évaluation: Taux de mortalité liée à une cause spécifique associés avec différents modes de vie, dont les habitudes alimentaires, le tabagisme et la consommation d'alcool. Pour cette analyse la base d'évaluation principale était la démence sénile, avec ou sans lésions cérébrovasculaires, comme cause direct du décès, ou à l'origine du décès, ou comme maladie coexistante.

Résultats: Le risque de décès rapporté comme démence sénile sans lésions cérébrovasculaires $(n=120)$, en majorité des décès dus à la maladie d'Alzheimer, était nettement plus élevé chez les fumeurs de cigarettes que chez les personnes n'ayant jamais fumé (risque relatif $1 \cdot 61,90 \%$ intervalle de confiance $1 \cdot 10$ à $2 \cdot 38$; deux faces $\mathrm{p}=0.042$ ). Une dose réponse significative, a été observée chez les hommes de 75 ans et plus, avec des risques relatifs pour les personnes n'ayant jamais fumé et pour les fumeurs quotidiens de $1-14,15-19$, et $\geqslant 20$ cigarettes par jour respectivement égal à 1·00, 1·73, 3.15 (deux faces $\mathrm{p}=0,036$ pour tendance). Une tendance similaire a été observée chez les hommes de 70 ans et plus.

Conclusions: Bien que l'on ne puisse pas complètement exclure que des causes cérébrovasculaires de décès faussement considérés comme démence sénile, l'association positive entre la consommation de cigarettes et la démence sénile sans lésions cérébrovasculaires fournit des raisons supplémentaires pour la prévention et la cessation du tabagisme.
Gran estudio de cohorte sobre la relación entre el tabaquismo y la demencia senil sin lesiones cerebrovasculares

Takeshi Hirayama

\section{Resumen}

Objetivo: Examinar la asociación entre la demencia senil y el tabaquismo.

Diseño: Estudio de cohorte prospectivo con 17 años de seguimiento (1966-82).

Sujetos: 265,118 adultos $>40$ años de edad ( $95 \%$ de la muestra del censo de población), residentes de 29 distritos sanitarios en seis prefecturas del Japón.

Medidas principales de desenlace: Tasas de mortalidad por causas específicas vinculadas con diversos estilos de vida, en particular alimentación, tabaquismo y consumo de alcohol. Para este análisis las medidas principales de desenlace fueron la demencia senil con o sin lesiones cerebrovasculares como causa directa o subyacente de la muerte o como enfermedad coexistente.

Resultados: El riesgo de muerte notificada como demencia senil sin lesiones cerebrovasculares $(n=120)$, representada principalmente por enfermedad de Alzheimer, fue significativamente mayor en los fumadores de cigarrillos en relación con las personas que nunca habian fumado (riesgo relativo 1,61; intervalo de confianza de $90 \%, 1,10$ a 2,38; prueba bilateral, $\mathrm{p}=$ $0,042)$. Se observó una relación dosis-respuesta significativa en los varones de 75 años o más; los riesgos relativos para los que nunca fumaron y para los fumadores de 1 a 14,15 a 19 y $>20$ cigarrillos por día fueron, respectivamente, $1,00,1,73,3,15$, y 3,10 , (prueba bilateral, $\mathrm{p}=0,036$ para la tendencia). Una tendencia similar se observó en los hombres de 70 años o más.

Conclusiones: Aunque no puede descartarse del todo que las causas cerebrovasculares de defunción tales como la demencia senil se hayan clasificado erróneamente, la asociación positiva entre el tabaquismo y la demencia senil sin lesiones cerebrovasculares viene a dar mayor fundamento a la prevención y el abandono del tabaquismo.

\section{吸烟与无脑血管损伤的老年性痴呆关系的大规模的队列研究}

研究目的：调查老年性知呆与吸烟之间的关系

研究设计：前瞻性队列研究，随访 17 年（从1966年至 1982 年)

研究对象：在日本六个地区 29 个医疗中心所管辖的 265,118 名 40 岁以上的成年人（占相应 地区普查人口的 $95 \%$ )

主要结果指标：饮食、吸烟和饮酒等各种生活方式的单因死亡率。在本研究中, 将有脑血管 损伤和无脑血管损伤的老年性疾呆作为直接死因、主要死因和伴随疾病。

研究结果：对于报告为无脑血管损伤的老年性痴呆 (多数为早期老年性椥朵) 的死亡危险 性: 吸烟者显著高于不吸烟者 $(\mathrm{RR}=1.61,95 \% \mathrm{CI}=1.10 \sim 2.38$, 双侧检验 $\mathrm{P}=0.042)$ ）在 75 岁以上的男性中, 观察到显著的剂量反应关系: 不吸烟、每天 1-14支、每天 15-19 支和每 天 20 及以上的相对危险度分别为 $1.00 、 1.73 、 3.15$ 和 3.10 (双侧趋势检验 $\mathrm{P}=0.036$ ) 相似 的趋势在 70 岁以上男性中也可以观察到。

结论: 尽管不叮能完全排除将其他脑血管疾病错分为老年性知呆的叮能性, 但足吸烟与无脑 血管损伤的老年性施呆之间的正相关为反吸烟运动又提供了进一步的证据。 